\title{
ギャンブル障害に対する心理学的アプローチの展開 \\ —IR 推進法に伴うカジノ設置に向けて—— \\ Future directions in the research and practice of psychological aproachs for gambling disorders: \\ Legalized casinos have been set up as a result of the enactment of the Integrated Resort Promotion Bill
}

\author{
特集号編集委員 岸 太一 小関 俊祐 \\ Special Issue Editors Taichi Kishi and Koseki Shunsuke
}

2016 年（平成 28 年）に「特定複合観光施設区域の整備の推進に関する法律（衆議院，2016）」(いわ ゆる IR 推進法）が成立したことに伴い，カジノ設置を見すえた政策の整備の一環として，ギャンブル 障害（いわゆるギャンブル依存）への対策が急務とされている。ギャンブル障害への対策としては，環 境や制度面の整備が重要な課題となる一方で，各個人への具体的な支援を念頭においた心理学的介入の 確立もまた期待されるところである。

これまでに，わが国では依存に関する問題への対策として，違法薬物への依存に対する心理学的な取 り組みが全国的に実施されている。この取り組みにおいては, リラプス・プリベンションのモデルに沿っ て米国で開発された Matrix プログラム（Rawson et al., 1995）に基づき，心理学的介入を比較的平易に 実施することが可能な支援方法の確立としてワークブックを用いることが試みられている。このような ワークブックをそのまま用いた取り組みは，心理学に精通しない者であっても実施できることが念頭に 置かれているため, ワークブックを使用してさえいれば心理学的介入を行うことができるという誤解が 生じてしまっていることが少なくない。

しかしながら，心理学的介入は，見立てに応じた介入を行うことによって十分な効果が期待される。 その点を踏まえると，ギャンブル障害への対策としての心理学的介入の確立を目指すにあたっては， ギャンブル障害を呈する個人の見立てと介入の方法について十分に検討し, さらにそれらの視点を有す る実施者の育成についても検討する必要がある。

以上の観点を踏まえ, 本特集では, ギャンブル障害に対する心理学的アプローチの展開として, ギャ ンブル障害に対する認知行動療法の研究と実践に関する今後の展望, 違法性を伴うギャンブルへの心理 学的アプローチの展望, アメリカの取り組み状況を踏まえた日本の取り組みの展望, の 3 つ展望論文 で構成されている。本特集によって, ギャンブル障害の治療的介入, 予防的介入を考えるに際し, 心理 学的アプローチのさらなる活用に向けた議論が深まることを期待したい。

\section{引用文献}

Rawson, R. A., Shoptaw, S. J., Obert, J. L., McCann, M. J., Hasson, A. L., Marinelli-Casey, P. J., ... Ling, W. (1995). An intensive outpatient approach for cocaine abuse treatment: The Matrix model. Journal of substance abuse treatment, 12, 117-127.

衆議院 (2016). 衆法第 189 回国会 20 特定複合観光施設区域の整備の推進に関する法律案 衆議院 Retrieved from http://www.shugiin.go.jp/internet/itdb_gian.nsf/html/gian/honbun/g18901020.htm (2017 年 9 月 27 日) 